\title{
Overlap at the molecular and immunohistochemical between angioimmunoblastic T-cell Iymphoma and a subgroup of peripheral T-cell lymphomas without specific morphological features
}

\author{
Rebeca Mansoํ, Julia González-Rincón ${ }^{2,5}$, Manuel Rodríguez-Justo ${ }^{3}$, Giovanna \\ Roncador ${ }^{4}$, Sagrario Gómez ${ }^{2}$, Margarita Sánchez-Beato ${ }^{2}$, Miguel A. Piris ${ }^{1,5}$ and \\ Socorro M. Rodríguez-Pinilla ${ }^{1,5}$ \\ ${ }^{1}$ Pathology Department, Fundación Jiménez Díaz, UAM, Madrid, Spain \\ ${ }^{2}$ Instituto Investigación Sanitaria Puerta de Hierro-Segovia de Arana (IDIPHIM), Madrid, Spain \\ ${ }^{3}$ UCL Cancer Institute, Department of Research Pathology, London, UK \\ ${ }^{4}$ Monoclonal Antibodies Unit, Biotechnology Programme, Spanish National Cancer Research Centre (CNIO), Madrid, Spain \\ ${ }^{5}$ Centro de Investigación Biomédica en Red Cáncer (CIBERONC), Madrid, Spain \\ Correspondence to: Socorro M. Rodríguez-Pinilla, email: smrodriguez@fjd.es \\ Keywords: AITL; PTCL; $T_{F H}$-phenotype; IHQ; NGS \\ Received: August 02, 2017 Accepted: February 21,2018 Epub: March 01, 2018 Published: March 23, 2018 \\ Copyright: Manso et al. This is an open-access article distributed under the terms of the Creative Commons Attribution License \\ 3.0 (CC BY 3.0), which permits unrestricted use, distribution, and reproduction in any medium, provided the original author and \\ source are credited.
}

\section{ABSTRACT}

The overlap of morphology and immunophenotype between angioimmunoblastic T-cell lymphoma (AITL) and other nodal peripheral T-cell lymphomas ( $\mathrm{n}$-PTCLs) is a matter of current interest whose clinical relevance and pathogenic background have not been fully established. We studied a series of 98 n-PTCL samples (comprising 57 AITL and 41 PTCL-NOS) with five $T_{F H}$ antibodies (CD10, BCL-6, PD-1, CXCL13, ICOS), looked for mutations in five of the genes most frequently mutated in AITL (TET2, DNMT3A, IDH2, RHOA and PLCG1) using the Next-Generation-Sequencing Ion Torrent platform, and measured the correlations of these characteristics with morphology and clinical features. The percentage of mutations in the RHOA and TET2 genes was similar (23.5\% of cases). PLCG1 was mutated in $14.3 \%, I D H 2$ in $11.2 \%$ and DNMT3A in $7.1 \%$ of cases, respectively. In the complete series, mutations in $R H O A$ gene were associated with the presence of mutations in IDH2, TET2 and DNMT3A $(p<0.001, p=0.043$, and $p=0.029$, respectively). Fourteen cases featured RHOA mutations without TET2 mutations. A close relationship was found between the presence of these mutations and a $T_{F H}$-phenotype in AITL and PTCL-NOS patients. Interestingly, BCL-6 expression was the only $T_{F H}$ marker differentially expressed between AITL and PTCL-NOS cases. There were many fewer mutated cases than there were cases with a $T_{F H}$ phenotype. Overall, these data suggest alternative ways by which neoplastic T-cells overexpress these proteins. On the other hand, no clinical or survival differences were found between any of the recognized subgroups of patients with respect to their immunohistochemistry or mutational profile. 


\section{INTRODUCTION}

Peripheral T-cell lymphomas (PTCLs) are a heterogeneous group of non-Hodgkin lymphomas (NHLs), characterized by their striking clinical and biological heterogeneity and non-specific therapeutic regimens. In our field, nodal PTCLs (n-PTCLs) are the most frequently diagnosed, and these may be classified into three subgroups: angioimmunoblastic T-cell lymphoma (AITL), peripheral T-cell lymphoma without specific features (PTCL-NOS), and ALK-positive and ALK-negative anaplastic large T-cell lymphoma (ALCL). Diagnostic criteria to distinguish between AITL and PTCL-NOS are mainly based on morphological examination, although an intermediate category has been recognized (PTCL-NOS with $\mathrm{T}_{\mathrm{FH}}$ markers) [1]. Gene expression array studies indicated that AITL samples were significantly enriched in genes up-regulated in $\mathrm{T}_{\mathrm{FH}}$ cells [2-4]. Furthermore, the molecular signature of CD30-negative PTCL-NOS partially overlapped with that of $\mathrm{T}_{\mathrm{FH}}$ cells, although the correlation was not as strong as that with AITLs [2], suggesting that the AITL spectrum may be wider than suspected, as a subset of CD30(-) PTCL-NOs may derive from, or be related to, AITL [2]. We and other researchers have shown that there is also overlap between AITL and some PTCL-NOSs at the morphological and immunohistochemical profile levels [2-4]. Recently, it has been shown that some of these PTCL cases also share most of the molecular background described in AITL samples $[2,4-7]$. Tumors that share the $\mathrm{T}_{\mathrm{FH}}$ immunophenotype (more than two $\mathrm{T}_{\mathrm{FH}}$ markers) are recognized as the PTCL with $\mathrm{T}_{\mathrm{FH}}$ phenotype and occupy a distinct provisional category in the new WHO classification [1]. Nevertheless, the criteria for identifying these patients and their clinical characteristics are not currently fully defined. We have studied a series of 98 n-PTCLs samples (comprising 57 AITL and 41 PTCL-NOS cases) with five $\mathrm{T}_{\mathrm{FH}}$ antibodies (CD10, BCL-6, PD-1, CXCL13, ICOS), and looked for mutations in five of the genes most frequently mutated in AITL (TET2, DNMT3A, IDH2, RHOA, PLCG1) using the NGS Ion Torrent platform. We have examined the associations of these characteristics with morphological and clinical features. We found a tendency for mutated genes and $\mathrm{T}_{\mathrm{FH}}$ markers to cluster independently and with each other. Although more frequently found in the AITL patients, a cluster of cases carrying mutated genes and $\mathrm{T}_{\mathrm{FH}}$ markers were also found in the PTCL-NOS subgroup of tumors.

\section{RESULTS}

\section{Immunohistochemical study}

According to the revised version of the WHO classification of lymphoid tumors, the $\mathrm{T}_{\mathrm{FH}}$ phenotype is defined as the expression of two or more (ideally, three)
$\mathrm{T}_{\mathrm{FH}}$-related proteins. However, neither the specific markers nor the intensity and percentage of positive cells have been defined precisely. Accordingly, 89.7\% (61/68) of our cases had a $\mathrm{T}_{\mathrm{FH}}$ phenotype when only $10 \%$ of tumoral cells (defined as atypical T-cells) expressed at least two of the markers studied ( $\mathrm{T}_{\mathrm{FH}}-1$ group). When the cut-off value for the presence of positive cells for each marker was set at $50 \%$ for each marker $51.5 \%(35 / 68)$ of cases were of the $\mathrm{T}_{\mathrm{FH}}$ phenotype $\left(\mathrm{T}_{\mathrm{FH}}-2\right.$ group). The presence of $\mathrm{T}_{\mathrm{FH}}$ markers occurred at a higher frequency in AITL than PTCL-NOS cases (Supplementary Table 1) $(p=0.068$ with two or more markers; $p=0.059$ with three or more markers). On the basis of clusters 1 and 2 (Figures 1 and 2) a 10\% cutoff value was chosen for use in the subsequent study.

The most frequently found positive $\mathrm{T}_{\mathrm{FH}}$ marker was CXCL13, which was positive in $72.94 \%(62 / 85)$ of cases, followed by PD-1 (71.42\%, 45/63 cases), BCL-6 (64.63\%, 53/82 cases), ICOS (50.63\%, 40/79 cases) and CD10 (10.39\%, 8/77).

The percentage of positive markers in the AITL group was $77.5 \%$ (31/40) for PD-1, 76.9\% (40/52) for BCL-6, 73.6\% (39/53) for CXCL13, 56.3\% (27/48) for ICOS and $14.9 \%$ (7/47) for CD10. In analyzing the PTCLNOS group, the highest frequency of staining was seen in CXCL13 (71.9\%, 23/32), followed by PD-1 (60.9\%; 14/23), BCL-6 (43.3\%; 13/30), ICOS $(41.9 \%, 13 / 31)$ and CD10 $(3.3 \% ; 1 / 30)$. BCL-6 was the only marker differentially expressed between the two subgroups, whereby there was a significantly higher level of expression in the AITL subgroup ( $p=0.002$ ) (Supplementary Table 2). Double immunohistochemistry for BCL-6/PD-1 was performed on TMA sections. Thirty-two of 79 valuable cases $(40.5 \%)$ expressed both markers, being more frequent in the AITL subgroup of tumors $(p=0.038)$ (Supplementary Table 2 and Supplementary Figure 1).

Four AITL cases $(7 \%)$ showed no $\mathrm{T}_{\mathrm{FH}}$ markers (Supplementary Table 1).

\section{Mutational study}

An equal percentage of cases $(23.5 \%)$ exhibited mutations in the RHOA and TET2 genes. PLCG1, IDH2 and DNMT3A were mutated in $14.3 \%$ (14/98), $11.2 \%$ (11/98) and $7.1 \%$ (7/98) of the cases (Supplementary Table 3).

The percentage of mutations varied between the tumors subgroups. In AITL cases, RHOA, TET2, IDH2, PLCG1 and DNMT3A were mutated in 35.1\% (20/57), $29.8 \%(17 / 57), 14.03 \%(8 / 57), 14.03 \%(8 / 57)$ and $8.8 \%$ $(5 / 57)$ of the cases, respectively (Figure 2).

Conversely, in PTCL-NOS, TET2, PLCG1, RHOA, $I D H 2$ and DNMT3A were mutated in $14.6 \%(6 / 41), 14.6 \%$ (6/41), $7.3 \%(3 / 41), 7.3 \%(3 / 41)$, and $4.9 \%(2 / 41)$ of the cases, respectively (Figure 2).

Only the expression of mutations in the RHOA gene differed between AITL and PTCL-NOS tumors ( $p=$ 0.001) (Supplementary Table 4). 
The G17V change was the only mutation found in the RHOA gene, the alteration occurring in the GTPbinding domain of $R H O A$ predicted to have a damaging function (Supplementary Figure 2). TET2 was the only gene in which two simultaneous mutations were found in two independent cases each, both of them being AITL cases (cases 31 and 39). Most of these gene alterations were missense mutations ( $52 \%$ of cases), mutations leading to premature stop codons ( $52 \%$ of cases) or alterations in splice sites (8.7\%). The same TET2-L1340R mutation was found in two cases. This alteration is predicted to have a damaging function and has also been described in at least two previous independent studies [8,9]. The profile of mutations in the DNMT3A gene was similar, with $71.4 \%$ missense mutations, $14.2 \%$ mutations leading to premature stop codons and $14.2 \%$ of alterations in splice sites. Again, only two (R736C and V690D) of the seven mutations $(28.6 \%)$ found had been previously described $[8,10]$.

Mutations in the $\mathrm{IDH} 2$ gene were all missense mutations affecting the same codon, although they give rise to different substitutions (four R172S, four R172G and three R172K). All these mutations have been predicted to have a damaging function.

We had previously used qPCR for the PLCG1 gene analysis to identify $10 / 98$ cases $(10.2 \%)$ in this series (represented in black in the cluster) with the PLCG1S345F mutation (6 AITL and 4 PTCL-NOS) [11]. We have identified four other mutations, three of them missense mutations (Y509H; G1248A and E589V) and one of them an alteration in the 3 'UTR region. None of them has been previously described.

In the whole series, mutations in the RHOA gene were related to the presence of mutations in the $I D H 2$, TET2 and DNMT3A genes ( $p<0.005 ; p<0.043$; and $p<$ 0.029 , respectively). No associations were found between any of the other genes. One of the cases with two double TET2 mutations also had a DNMT3A mutation, while none of these cases showed alterations in the RHOA gene.

The variant allele frequency was higher for TET2 mutations (median, 25.22\%; range, 5-64 alleles per case) than for RHOA mutations (median, 12.65\%; range 5-34 alleles per case). There were 14 cases with $R H O A$ mutations without TET2 mutations. Six of these cases had IDH2 mutations, one had a DNMT3A gene mutation and another had a mutation in both the $I D H 2$ and $D N M T 3 A$ genes. Only two of the cases with both the RHOA and $I D H 2$ mutations showed a greater than $10 \%$ variant allele frequency for the two genes (cases 45 and 48). Six further cases showed no other change in any of these epigeneticrelated genes, four of which had a variant allele frequency greater than 10\% (Supplementary Table 3).

In the AITL subgroup of tumors, the relationship between mutations in the RHOA gene with mutations in both IDH2 and DNMT3A $(p<0.005$ and $p=0.0028)$ was maintained, while the relationship with mutations in the TET2 gene was lost. By contrast, in the PTCLNOS subgroup of tumors, mutations in the RHOA gene were associated with IDH2 $(p<0.005)$ and PLCG1 $(p$ $=0.008$ ) gene mutations. A strong positive relationship was also found between IDH2 and PLCG1 $(p=0.008)$. Interestingly, $42.1 \%(24 / 57)$ of AITL cases did not show any of these studied mutations (Figure 1).

No correlations were found between any individual mutation or mutational combination with any of the analyzed clinical parameters (Supplementary Tables 5-9).

\section{Correlations between the presence of $T_{F H}$ markers and mutations in selected genes}

In the whole series, the expression of PD-1 was significantly positively correlated with the presence of mutations in the TET2 $(p=0.044)$ and PLCG1 $(p=$ $0.034)$ genes. CXCL13 was positively correlated with the presence of RHOA mutations ( $p=0.002)$. CD10 was correlated with the presence of mutations in the PLCG1 $(p=0.05)$ and RHOA $(p<0.001)$ genes (Supplementary Table 10). In the AITL subgroup of tumors the correlations between CXCL13 expression and RHOA mutations ( $p=$ 0.001), and between CD10 expression and PLCG1 ( $p$ $=0.027)$ and RHOA $(p=0.003)$ gene mutations were maintained. Moreover, a positive association was found between the expression of CD10 and the occurrence of mutations in the TET2 gene $(p=0.010)$.

A trend between the $\mathrm{T}_{\mathrm{FH}^{-1}}-1$ group and RHOA gene mutations was found ( $p=0.068$ ) while no correlations were found regarding $\mathrm{T}_{\mathrm{FH}}-2$ group. Moreover, the presence of three or more $\mathrm{T}_{\mathrm{FH}}$ markers was related to the presence of RHOA gene mutations ( $p=0.004)$.

The presence of double immunohistochemical expression of BCL-6/PD-1 was positively correlated with the presence of mutations in the RHOA ( $p=0.004), I D H 2$ $(p=0.036)$ and PLCG1 $(p=0.009)$ genes (Supplementary Table 10).

\section{DISCUSSION}

In the present series, and in accordance with other published reports $[8,12-14]$, the presence of $\mathrm{T}_{\mathrm{FH}}$ markers was broadly associated with AITL morphology. All $\mathrm{T}_{\mathrm{FH}}$ markers tended to cluster together, and mutations in the five genes studied also clustered together, occurring at a higher frequency in the AITL subgroup of tumors. However, a subgroup of PTCL-NOS showing mutations in these genes as well as a $\mathrm{T}_{\mathrm{FH}}$ phenotype could also be identified. Additionally, some AITL cases lack $\mathrm{T}_{\mathrm{FH}}$ markers or the distinctive mutational events. Thus, a grey area can be identified between a cluster of AITL cases with typical morphology, multiple $\mathrm{T}_{\mathrm{FH}}$ markers and presence of mutated genes with PTCL-NOS without any $\mathrm{T}_{\mathrm{FH}}$ marker or mutated gene. We have looked for clinical correlations that could help to identify thresholds or case clusters, but failed 


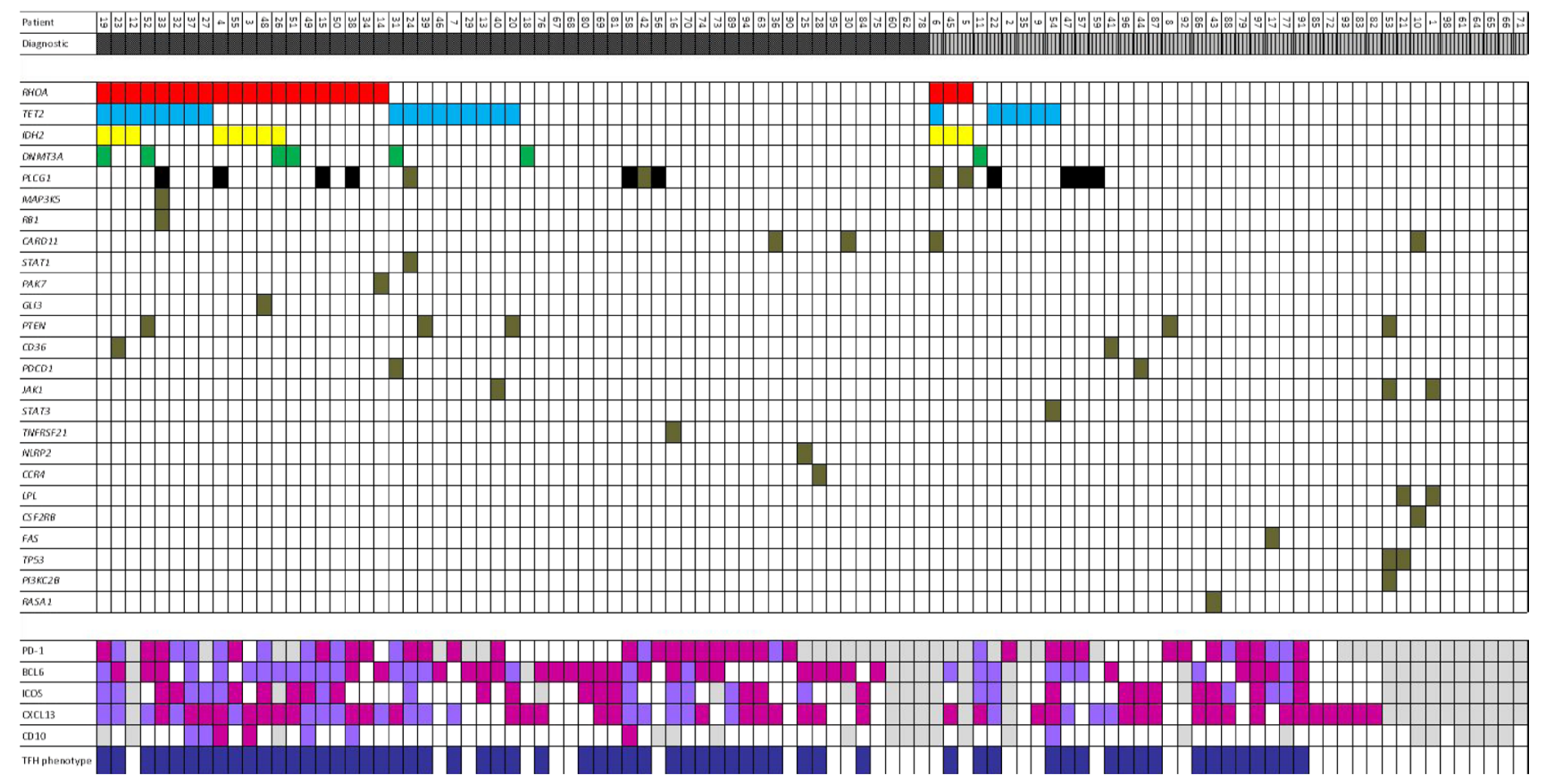

Figure 1: Representative association between mutations of selected genes and $T_{F H}$ markers in $n-P T C L$ according to morphology. Dark grey: AITL; Light grey with stripes: PTCL-NOS; Dark blue: $\mathrm{T}_{\mathrm{FH}}$-phenotype; White: wild-type/no expression; Purple: $\mathrm{T}_{\mathrm{FH}}>10 \%$; Fuchsia: $\mathrm{T}_{\mathrm{FH}}>50 \%$; Light grey: no data.

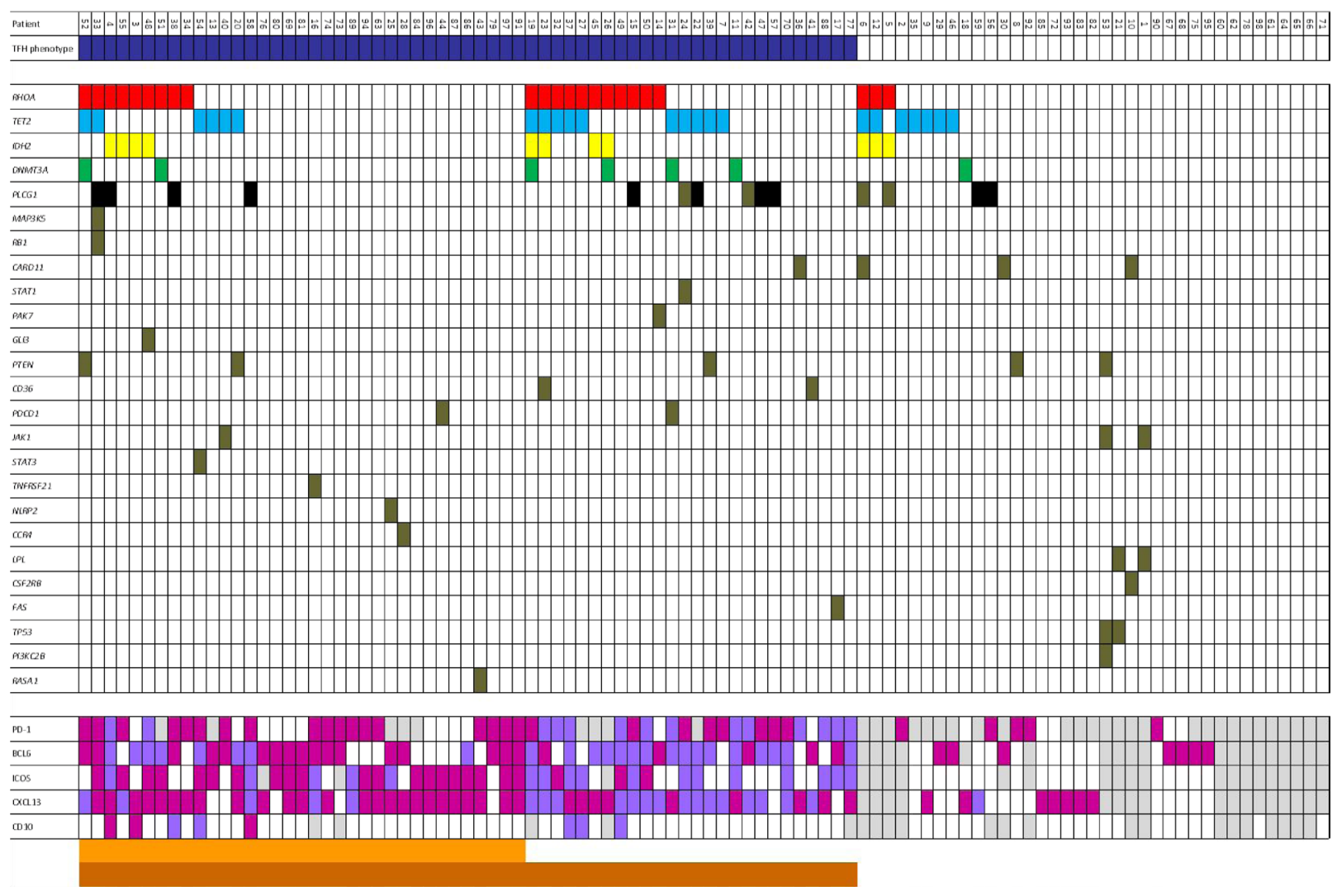

Figure 2: Representative association between mutations of selected genes and cases in n-PTCL according to presence/ absence of $\mathbf{T}_{\mathrm{FH}}$-phenotype. Dark blue: $\mathrm{T}_{\mathrm{FH}}$-phenotype; White: wild-type/no expression; Purple: $\mathrm{T}_{\mathrm{FH}}>10 \%$; Fuchsia: $\mathrm{T}_{\mathrm{FH}}>50 \%$; Dark orange: $0-1$ markers to $50 \%$; Orange: $2-5$ markers to $50 \%$; Light grey: no data. 
to identify any, although this could be due to the relatively small number of cases considered here.

In the present series, CXCL13, PD-1, BCL-6, ICOS and CD10 were the most frequently positive markers, occurring in $72.94 \%, 71.42 \%, 64.63 \%, 50.63 \%$ and $10.36 \%$ of cases, respectively. ICOS expression in this subgroup of patients has not been thoroughly studied. Most studies indicate that CXCL13 is the most frequently expressed gene in AITL and PTCL-NOS samples. Major differences arise from the low frequency of CD10positive cases found in this study, which could be due to the antibody used or the threshold applied. The level of expression of $\mathrm{T}_{\mathrm{FH}}$ markers in the PTCL-NOS subgroup of tumors is slightly higher than previously described, ranging from $11 \%$ to $61 \%$ across different series [4, 15-22]. This discrepancy could be due to an enrichment of PTCL-NOS cases with AITL-like morphology in the present series. $27.3 \%$ of the n-PTCL cases in this series exhibited four of the five markers analyzed. Only $7 \%$ of AITL cases showed none of the markers, while $43.9 \%$ of the PTCL-NOS showed at least two of them.

It is of particular note that BCL-6 was the main marker differentially expressed between AITL and PTLNOS cases. This relationship was maintained when double PD1/BCL-6 expressers were analyzed ( $p=0.038)$. Miyoshi et al. [18] reported a relationship between the expression of BCL-6 and AITL morphology. BCL-6 has been described as the master regulator of $\mathrm{T}_{\mathrm{FH}}$-cells, and can regulate and be regulated by the presence of other $\mathrm{T}_{\mathrm{FH}}$ cell markers [23]. Many $\mathrm{T}_{\mathrm{FH}}$ cell markers, such as CXCL13, PD-1 and CD10, can be seen in other T-cell lymphomas such as mycosis fungoides, Sézary syndrome, primary cutaneous $\mathrm{T}$-cell lymphoma with $\mathrm{T}_{\mathrm{FH}}$-phenotype, or in clonal proliferations of small- to medium-sized CD4positive T lymphocytes, but BCL-6 is rarely expressed $[20,24]$. It is not known whether the presence of BCL-6 is related to the difference in morphology between AITL and $\mathrm{T}_{\mathrm{FH}}$-PTCL-NOS, or if it has a role in a difference in the etiopathogenesis of these two tumor subgroups.

The percentage of mutated cases in the present series was lower than reported in previous studies (Supplementary Table 11). Variability of tumor-cell content, sequence coverage and efficacy of variant calling probably contributed most to the discrepancy with other reports, most of which found the highest mutation rate to be in the TET2 gene, followed by RHOA. Mutations of TET2, IDH2 and DNMT3A usually coexist in AITL patients, unlike the case of myeloid neoplasm, in which TET2 and IDH2 mutations appear to be mutually exclusive. Furthermore, the variant allele frequency is higher for TET2 and DNMT3A mutations than for RHOA mutations in AITL cases [9]. TET2 and DNMT3A mutations are thought to occur at an early stage of hematopoietic cell differentiation since they are also found in non-malignant hematopoietic cells, non-transformed CD20-positive immunoblasts in AITL patients, as well as in normal elderly individuals. Based on these observations, a multistage developmental pathway for AITL has been suggested, in which TET2 and DNMT3A are both early events related to enhanced self-renewal, while mutations in the RHOA gene, among others, are secondary events associated with the malignant transformation of lineage commitment [8-10, 25-28]. However, we found no relationship between TET2 and DNMT3A mutations, although one of the cases with mutations in both genes had two different mutations in the TET2 gene, in accordance with previous reports. Although the variant allele frequencies of the TET2 and DNMT3A genes were higher than that of the RHOA gene, we found six RHOA gene-mutated cases that had no other mutations in TET2, $D N M T 3 A$ or $I D H 2$. In the present series, all $I D H 2$-mutated cases also had RHOA gene mutations that were present in the AITL and PTCL-NOS patients. Although most authors suggest a close correlation between mutations in $\mathrm{IDH} 2$ and AITL morphology, only one study has yielded results that concur with ours [14].

Only mutations in the RHOA gene were differentially expressed between AITL and PTCL-NOS tumors $(p=0.001)$. AITL is pathologically characterized by marked proliferation of endothelial venules, expanded follicular dendritic cell (FDC) meshworks around the venules, diffuse polymorphic infiltrates, and the expansion of EBV-positive or EBV-negative B-immunoblasts [29]. Three histological patterns are recognized, of which the most common is absent follicles, although cases with depleted or hyperplastic follicles have also been described [30]. Our findings concur with those of two previous studies showing the association between the presence of the RHOA-G17V mutation and a classic AITL morphology with expanded dendritic meshwork and $\mathrm{T}_{\mathrm{FH}}$ phenotype [31, 32].

We and other researchers have described a relatively high percentage of AITL patients without mutations in any of the genes here mentioned. A priori, these results suggest that alternative pathogenic events play a role in the development of AITL, at least in a subgroup of these patients. So, alternative ways of changing the same or different genes in these pathways are probably responsible for the development of these non-mutated patients.

TET2 mutation is the only mutated gene known to be correlated with aggressive clinical features [22]. However, our data do not support this or any other association.

A close relationship was found between the presence of these mutations and a $\mathrm{T}_{\mathrm{FH}}$-phenotype in both AITL and $\mathrm{T}_{\mathrm{FH}}$-phenotype PTCL-NOS patients, suggesting the existence of a core of AITL cases carrying both $T_{\mathrm{FH}}$ phenotype and mutated genes. Nevertheless, the frequency of mutated cases was much lower than that of cases with a $\mathrm{T}_{\mathrm{FH}}$ phenotype $[23,33]$. No clinical or survival differences were found regarding these subgroups. Combinations of two, three and four $\mathrm{T}_{\mathrm{FH}}$ markers showed different correlations with mutated genes. RHOA gene mutations 
were associated with most combinations of $\mathrm{T}_{\mathrm{FH}}$-markers. PD-1/CD10 as well as double-expresser tumors for PD1 and BCL-6 proteins were correlated with the presence of most mutated genes (RHOA, IDH2 and PLCG1). No clinical differences were found in any association between gene mutations and $\mathrm{T}_{\mathrm{FH}}$-markers. These results make it very difficult to recommend which $\mathrm{T}_{\mathrm{FH}}$ proteins should be used to identify n-PTCL with $\mathrm{T}_{\mathrm{FH}}$ phenotype, but it is clear that the use of multiple markers should be accompanied by a standardization of the techniques and interpretation of results.

Except for the RHOA and IDH2 genes, the number and function of mutations in the other genes, especially TET2 and DNMT3A, are highly variable. This means that they are not very useful in daily clinical practice, although they may be of great biological significance, suggesting that AITL pathogenesis could arise in some cases from the clonal expansion of hematopoietic precursor cells. The presence of most of these mutations is not specific to AITL or other $\mathrm{T}_{\mathrm{FH}}$-PTCL-NOS cases, since they have also been found to be mutated in cutaneous T-cell lymphomas, Sézary syndrome, T-cell prolymphocytic leukemia, adult T-cell leukemia/lymphoma, acute lymphoblastic leukemia, T-cell and NK-cell post-transplant lymphoproliferative disorders, and in diffuse large B-cell lymphomas [34-44]. To the best of our knowledge, the IDH2 gene has not been found to be mutated in other subgroups of lymphomas, except for exceptional cases of lymphoblastic leukemia [45], making it somehow characteristic of these subgroups of tumors. Unfortunately, they were present in only $11.2 \%$ of our cases, compared with the highest reported rate of $33.3 \%$ [28]. Nevertheless, the knowledge of the mutational status of n-PTCL samples could be useful as markers for guiding future therapy or patient follow-up [46-48].

In conclusion, AITL differed from $\mathrm{T}_{\mathrm{FH}}$-PTCL-NOS cases with respect to morphology, BCL-6 expression and RHOA mutation rate, although none of these features had clinical implications. In general, the AITL and $\mathrm{T}_{\mathrm{FH}}-\mathrm{PTCL}-$ NOS subgroups of tumors share morphological features, immunophenotype, molecular background and clinical behavior. Considering all these features together could justify ascribing all these entities to a single category in the lymphoma classification [1].

\section{MATERIALS AND METHODS}

\section{Patient samples}

The series included 98 formalin-fixed, paraffinembedded (FFPE) n-PTCL cases (57 AITL and 41 PTCL-NOS). Diagnostic criteria were based on the WHO classification [1]. All samples were reviewed by two pathologists (SMR-P and MAP) to confirm the diagnoses. Patients' clinical data have been reported in previous publications [11, 12, 49-51]. Patient characteristics are presented in Supplementary Table 12. Samples and clinical data of patients included in the study were provided by several Spanish Biobanks. The project was supervised by the Ethical Committees of the Hospital Universitario Marqués de Valdecilla (Santander) and the Fundación Jiménez Díaz (Madrid).

\section{Tissue microarray construction}

Representative areas from FFPE lymphomas were carefully selected from H\&E-stained sections. Three tissue cores of $1 \mathrm{~mm}$ diameter were obtained from each specimen. The cores were precisely arrayed into a new paraffin block using a tissue microarray (TMA) workstation (Beecher Instruments, Silver Spring, MD).

\section{Immunohistochemical studies}

TMA sections were stained by the EndVision method with a heat-induced antigen-retrieval step for BCL-6, ICOS, CD10, PD-1 and CXCL13. Reactive tonsil tissue was included as a control. The primary antibodies were omitted to provide negative controls (Supplementary Table 13). Cases were considered to belong to the $\mathrm{T}_{\mathrm{FH}}{ }^{-}$ phenotype subgroup when at least two different markers were positive. Sixty-eight of 98 cases had valuable $\mathrm{T}_{\mathrm{FH}^{-}}$ phenotype data. Two groups were defined on the basis of the percentage of positive cells for each marker (group 1, $>10 \%$; group 2, $>50 \%$ ). Double immunohistochemistry for BCL-6/PD-1 was performed on TMA sections. Only 79 of the 98 cases produced valuable data.

\section{Double immunoenzymatic staining}

For paraffin-embedded tissues, an initial automated dewaxing and rehydration step followed by heat-induced $\left(100^{\circ} \mathrm{C}\right.$ for $20 \mathrm{~min}$ ) or enzyme-induced (10 to $15 \mathrm{~min}$, Bond Enzyme Pretreatment Kit, Leica Biosystems, Wetzlar, Alemania) antigen retrieval was performed. Heatinduced antigen retrieval was performed using $\mathrm{pH} 8.8$ ethylenediaminetetraacetic acid (EDTA)-based ready-touse solution (Leica Biosystems). Slides were subsequently incubated with $3 \%$ hydrogen peroxide ( $5 \mathrm{~min}$ ), optimally diluted primary antibody (15 to $30 \mathrm{~min}$ ), a postprimary blocking reagent (to prevent nonspecific polymer binding) (8 min), horseradish peroxidase-labeled polymer ( $8 \mathrm{~min})$, and diaminobenzidine substrate $(10 \mathrm{~min})$. All reagents were components of the Bond Polymer Refine detection system (Leica Biosystems). New adhesive labels needed for the second staining procedure were applied to the slides. A second immunophosphatase (AP) procedure was then performed, omitting the dewaxing, rehydration and epitope retrieval steps. The primary antibody was applied for $40 \mathrm{~min}$, followed by incubation with postprimary AP blocking reagent $(20 \mathrm{~min}$ ) and AP-labeled polymer (30 min), both of which are components of the Bond Polymer AP Red detection system (Leica Biosystems). The AP reaction was carried out with the Fast Red substrate 
included in the Bond Polymer AP Red detection system. Hematoxylin counterstaining was performed.

\section{DNA extraction}

We extracted genomic DNA (DNAg) of tumoral FFPE samples using a QIAamp ${ }^{\circledR}$ DNA FFPE Tissue kit (Qiagen Inc., Valencia, CA, USA) in accordance with the manufacturer's protocol. DNAs were quantified with Qubit $^{\mathbb{\circledR}}$ (Invitrogen, Carlsbad, CA, USA). The quantity and quality of DNAs used in constructing libraries for nextgeneration sequencing (NGS) were assessed using the KAPA Human Genomic DNA Quantification and QC kit (KAPA Biosystems Inc., Roche) and the 7500 Real Time System (Applied Biosystems, Foster City, CA, USA) in accordance with the manufacturer's protocol.

\section{Detection of PLCG1 mutation by qPCR}

We used two previously described methods $[11,41]$ two detect the S345F mutation of PLCG1.

\section{NGS Custom Panel design}

The Ion kit AmpliSeq ${ }^{\mathrm{TM}}$ Library kit (Life Technologies, Carlsbad, California, USA) panel includes 48 genes being previously found mutated in T-cell lymphomas (Supplementary Table 14) and it was designed using AmpliSeq ${ }^{\mathrm{TM}}$ Custom Ion panel Designer (Life Technologies) (https://www.ampliseq.com/browse.action).

\section{Library preparation and sequencing}

For targeted sequencing we used $30 \mathrm{ng}$ DNAg and the Ion AmpliSeq ${ }^{\text {TM }}$ custom panel technology (Life Technologies), following the standard protocol. The quantification of amplifiable library molecules is critical for the efficient use of the Ion Torrent NGS platform; we performed the qPCR using the Library Quantitation kit (Life Technologies) and the StepOne ${ }^{\mathrm{TM}}$ System (Applied Biosystems, Foster City, CA, USA) in accordance with the manufacturer's protocol. We then prepared and enriched the template DNA by PCR emulsion performed on Ion Sphere Particles (ISPs). Libraries were sequenced using the Ion Proton $^{\mathrm{TM}}$ instrument according to the manufacturer's protocol.

\section{Bioinformatic analysis}

The reads obtained with the sequencer were analyzed using the integrated Torrent Suite system (Life Technologies). The sequences were aligned with the reference genome NCBI Build 37 (UCSC hg19) using TMAP-Ion-Alignment software. The variants were then identified by the Torrent Variant Caller algorithm and the variants were annotated with the Ion Reporter (Life Technologies). Relevant somatic mutations were called and filtered by excluding: (i) synonymous SNVs; (ii) known variants listed in SNP databases (as described above); (iii) variants only present in unidirectional reads; (iv) variants occurring in repetitive genomic regions; (v) variants with coverage of $<30 \mathrm{X}$; (vi) variants with fewer than five reads in tumor samples; and (vii) mutations with a Variant Allele Frequency (VAF) of $<0.05$. The variants were visually checked using Integrated Genome Viewer (IGV v2.3; Broad Institute) to exclude artifacts and sequencing errors. The COSMIC (Catalogue of Somatic Mutations in Cancer) database was checked to identify pathogenetic changes. In addition, the variants were analyzed with two mutational functional prediction programs (SIFT and Polyphen-2).

\section{Statistical analysis}

To assess associations between categorical variables, we used the $\mathrm{X}^{2}$ contingency test with Yates' correction, or Fisher's exact test, as appropriate. Overall survival (OS) was taken as the period between the date of diagnosis and the date of death from any cause, or of last contact for living patients. Disease-specific OS was calculated as the period from date of diagnosis until death from the tumor. Kaplan-Meier survival analyses were carried out for OS and lymphoma-specific survival, using the log-rank test to examine differences between groups. A multivariate Cox regression model was also derived. Estimates were considered statistically significant for two-tailed values of $p<0.05$. All analyses were carried out with SPSS v.20.0 (IBM Corp., Armonk, NY, USA) [51].

\section{Author contributions}

MAP and SMRP conceived and designed the study. RM, JGR, MRJ, GR, SG, MSB, MAP and SMRP performed the experiments and/or analyzed data. RM, MAP and SMRP wrote the manuscript. The authors declare no competing financial interests.

\section{ACKNOWLEDGMENTS}

We are indebted to the patients who contributed to this study and to the hospitals who supplied the samples. We acknowledge the staff of the Biobanks of the CNIO (RD09/0076/00113), IDIVAL-HUMV (RD09/0076/00076), Hospital Universitario 12 de Octubre (RD09/0076/00118), CHUVI (RD09/0076/00011) and FJD (PT13/0010/0012), especially Laura Cereceda, for their help in collecting the samples.

\section{CONFLICTS OF INTEREST}

None of the authors reports any conflicts of interest. 


\section{FINANCIAL SUPPORT}

This work was supported by grants from the Instituto de Salud Carlos III, from the Ministerio de Economía, Industria y Competitividad (RTICC RD06/0020/0107, RD12/0036/0060, PI 12/1682, PT13/0010/0007, PI16/ 01294, SAF2013-47416-R, CIBERONC-ISCIII, PIE15/ 0081, ISCIII-MINECO AES-FEDER (Plan Estatal I+D+I 2013-2016): PI14/00221, PIE14/0064, PIE15/0081 and PIE16/01294)) and the Asociación Española Contra el Cáncer, Spain. JG-R is a recipient of an iPFIS predoctoral fellowship (IFI14/00003) from ISCIII-MINECO-AESFEDER (Plan Estatal I+D+I 2013-2016). MSB was supported by a Miguel Servet contract (CP11/00018) from the ISCIII-MINECO-AES-FEDER (Plan Nacional I+D+I 2008-2011), and currently holds a Miguel Servet II contract (CPII16/00024), supported by ISCIII-MINECOAES-FEDER (Plan Estatal I+D+I 2013-2016) and the Fundación de Investigación Biomédica Puerta de Hierro.

\section{REFERENCES}

1. Swerdlow SH, Harris NL, Jaffe ES, Pileri SA, Stein $\mathrm{H}$, Thiele J. WHO Classification of Tumours of Haematopoietic and Lymphoid Tissues. Revised 4th edition. Lyon: IARC; 2017.

2. de Leval L, Rickman DS, Thielen C, Reynies A, Huang YL, Delsol G, Lamant L, Leroy K, Brière J, Molina T, Berger F, Gisselbrecht C, Xerri L, Gaulard P. The gene expression profile of nodal peripheral T-cell lymphoma demonstrates a molecular link between angioimmunoblastic T-cell lymphoma (AITL) and follicular helper T (TFH) cells. Blood. 2007; 109:4952-63. https://doi.org/10.1182/ blood-2006-10-055145.

3. Piccaluga PP, Agostinelli C, Califano A, Carbone A, Fantoni L, Ferrari S, Gazzola A, Gloghini A, Righi S, Rossi M, Tagliafico E, Zinzani PL, Zupo S, et al. Gene expression analysis of angioimmunoblastic lymphoma indicates derivation from $\mathrm{T}$ follicular helper cells and vascular endothelial growth factor deregulation. Cancer Res. 2007; 67:10703-10. https://doi. org/10.1158/0008-5472.CAN-07-1708.

4. Rodríguez-Pinilla SM, Atienza L, Murillo C, PérezRodríguez A, Montes-Moreno S, Roncador G, PérezSeoane C, Domínguez P, Camacho FI, Piris MA. Peripheral T-cell lymphoma with follicular T-cell markers. Am J Surg Pathol. 2008; 32:1787-99. https://doi.org/10.1097/ PAS.0b013e31817f123e.

5. Huang Y, Moreau A, Dupuis J, Streubel B, Petit B, Le Gouill S, Martin-Garcia N, Copie-Bergman C, Gaillard F, Qubaja M, Fabiani B, Roncador G, Haioun C, et al. Peripheral T-cell lymphomas with a follicular growth pattern are derived from follicular helper T cells (TFH) and may show overlapping features with angioimmunoblastic T-cell lymphomas. Am J Surg Pathol. 2009; 33:682-90. https://doi.org/10.1097/PAS.0b013e3181971591.
6. Agostinelli C, Hartmann S, Klapper W, Korkolopoulou P, Righi S, Marafioti T, Piccaluga PP, Patsouris E, Hansmann ML, Lennert K, Pileri SA. Peripheral T cell lymphomas with follicular $\mathrm{T}$ helper phenotype: a new basket or a distinct entity? Revising Karl Lennert's personal archive. Histopathology. 2011; 59:679-91. https://doi. org/10.1111/j.1365-2559.2011.03981.x.

7. Pileri SA. Follicular helper T-cell-related lymphomas. Blood. 2015; 126:1733-34. https://doi.org/10.1182/ blood-2015-08-665075.

8. Palomero T, Couronné L, Khiabanian H, Kim MY, AmbesiImpiombato A, Perez-Garcia A, Carpenter Z, Abate F, Allegretta M, Haydu JE, Jiang X, Lossos IS, Nicolas C, et al. Recurrent mutations in epigenetic regulators, RHOA and FYN kinase in peripheral T cell lymphomas. Nat Genet. 2014; 46:166-70. https://doi.org/10.1038/ng.2873.

9. Sakata-Yanagimoto M, Enami T, Yoshida K, Shiraishi Y, Ishii R, Miyake Y, Muto H, Tsuyama N, Sato-Otsubo A, Okuno Y, Sakata S, Kamada Y, Nakamoto-Matsubara R, et al. Somatic RHOA mutation in angioimmunoblastic $\mathrm{T}$ cell lymphoma. Nat Genet. 2014; 46:171-75. https://doi. org/10.1038/ng.2872.

10. Odejide $\mathrm{O}$, Weigert $\mathrm{O}$, Lane AA, Toscano D, Lunning MA, Kopp N, Kim S, van Bodegom D, Bolla S, Schatz JH, Teruya-Feldstein J, Hochberg E, Louissaint A, et al. A targeted mutational landscape of angioimmunoblastic T-cell lymphoma. Blood. 2014; 123:1293-96. https://doi. org/10.1182/blood-2013-10-531509.

11. Manso R, Rodríguez-Pinilla SM, González-Rincón J, Gómez S, Monsalvo S, Llamas P, Rojo F, Pérez-Callejo D, Cereceda L, Limeres MA, Maeso C, Ferrando L, Pérez-Seoane C, et al. Recurrent presence of the PLCG1 $\mathrm{S} 345 \mathrm{~F}$ mutation in nodal peripheral T-cell lymphomas. Haematologica. 2015; 100:e25-27. https://doi.org/10.3324/ haematol.2014.113696.

12. Manso R, Sánchez-Beato $\mathrm{M}$, Monsalvo $\mathrm{S}$, Gómez $\mathrm{S}$, Cereceda L, Llamas P, Rojo F, Mollejo M, Menárguez J, Alves J, García-Cosio M, Piris MA, Rodríguez-Pinilla SM. The RHOA G17V gene mutation occurs frequently in peripheral T-cell lymphoma and is associated with a characteristic molecular signature. Blood. 2014; 123:289394. https://doi.org/10.1182/blood-2014-02-555946.

13. Vallois D, Dobay MP, Morin RD, Lemonnier F, Missiaglia E, Juilland M, Iwaszkiewicz J, Fataccioli V, Bisig B, Roberti A, Grewal J, Bruneau J, Fabiani B, et al. Activating mutations in genes related to TCR signaling in angioimmunoblastic and other follicular helper T-cellderived lymphomas. Blood. 2016; 128:1490-502. https:// doi.org/10.1182/blood-2016-02-698977.

14. Dobay MP, Lemonnier F, Missiaglia E, Bastard C, Vallois D, Jais JP, Scourzic L, Dupuy A, Fataccioli V, Pujals A, Parrens M, Le Bras F, Rousset T, et al. Integrative clinicopathological and molecular analyses of angioimmunoblastic T-cell lymphoma and other nodal lymphomas of follicular helper T-cell origin. Haematologica. 2017; 102:e148-51. https://doi. org/10.3324/haematol.2016.158428. 
15. Matsumoto $\mathrm{Y}$, Horiike $\mathrm{S}$, Ohshiro $\mathrm{M}$, Yamamoto M, Sasaki N, Tsutsumi Y, Kobayashi T, Shimizu D, Uchiyama H, Kuroda J, Nomura K, Shimazaki C, Taniwaki M. Expression of master regulators of helper $\mathrm{T}$-cell differentiation in peripheral T-cell lymphoma, not otherwise specified, by immunohistochemical analysis. Am J Clin Pathol. 2010; 133:281-90. https://doi.org/10.1309/ AJCP0SBHYVLY5EML.

16. Dupuis J, Boye K, Martin N, Copie-Bergman C, Plonquet A, Fabiani B, Baglin AC, Haioun C, DelfauLarue $\mathrm{MH}$, Gaulard P. Expression of CXCL13 by neoplastic cells in angioimmunoblastic T-cell lymphoma (AITL): a new diagnostic marker providing evidence that AITL derives from follicular helper $\mathrm{T}$ cells. Am J Surg Pathol. 2006; 30:490-94. https://doi. org/10.1097/00000478-200604000-00009.

17. Kerl K, Vonlanthen R, Nagy M, Bolzonello NJ, Gindre P, Hurwitz N, Gudat F, Nador RG, Borisch B. Alterations on the $5^{\prime}$ noncoding region of the BCL- 6 gene are not correlated with BCL- 6 protein expression in T cell nonHodgkin lymphomas. Lab Invest. 2001; 81:1693-702. https://doi.org/10.1038/labinvest.3780382.

18. Miyoshi H, Sato K, Niino D, Arakawa F, Kimura Y, Kiyasu J, Takeuchi M, Yoshida M, Okada Y, Nakamura Y, Sugita Y, Ohshima K. Clinicopathologic analysis of peripheral T-cell lymphoma, follicular variant, and comparison with angioimmunoblastic T-cell lymphoma: Bcl-6 expression might affect progression between these disorders. Am J Clin Pathol. 2012; 137:879-89. https://doi.org/10.1309/ AJCPBPNV86VZENGV.

19. Zaja F, Tabanelli V, Agostinelli C, Calleri A, Chiappella A, Varettoni M, Luigi Zinzani P, Volpetti S, Sabattini E, Fanin R, Pileri SA. CD38, BCL-2, PD-1, and PD-1L expression in nodal peripheral T-cell lymphoma: possible biomarkers for novel targeted therapies? Am J Hematol. 2017; 92:E1-2. https://doi.org/10.1002/ajh.24571.

20. Ahearne MJ, Allchin RL, Fox CP, Wagner SD. Follicular helper T-cells: expanding roles in T-cell lymphoma and targets for treatment. Br J Haematol. 2014; 166:326-35. https://doi.org/10.1111/bjh.12941.

21. Iqbal J, Weisenburger DD, Greiner TC, Vose JM, McKeithan T, Kucuk C, Geng H, Deffenbacher K, Smith L, Dybkaer K, Nakamura S, Seto M, Delabie J, et al, and International Peripheral T-Cell Lymphoma Project. Molecular signatures to improve diagnosis in peripheral T-cell lymphoma and prognostication in angioimmunoblastic T-cell lymphoma. Blood. 2010; 115:1026-36. https://doi.org/10.1182/ blood-2009-06-227579.

22. Lemonnier F, Couronné L, Parrens M, Jaïs JP, Travert M, Lamant L, Tournillac O, Rousset T, Fabiani B, Cairns RA, Mak T, Bastard C, Bernard OA, et al. Recurrent TET2 mutations in peripheral T-cell lymphomas correlate with TFHlike features and adverse clinical parameters. Blood. 2012; 120:1466-69. https://doi.org/10.1182/blood-2012-02-408542.

23. Manso R, Martínez-Magunacelaya N, Chamizo C, Rojo F, Piris MA, Rodriguez-Pinilla SM. Mutual regulation between BCL6 and a specific set of miRNAs controls TFHphenotype in peripheral T-cell lymphoma. $\mathrm{Br} \mathrm{J}$ Haematol. 2017. https://doi.org/10.1111/bjh.14824.

24. Santonja C, Soto C, Manso R, Requena L, Piris MA, Rodríguez-Pinilla SM. Primary cutaneous follicular helper T-cell lymphoma. J Cutan Pathol. 2016; 43:164-70. https:// doi.org/10.1111/cup.12614.

25. Quivoron C, Couronné L, Della Valle V, Lopez CK, Plo I, Wagner-Ballon O, Do Cruzeiro M, Delhommeau F, Arnulf B, Stern MH, Godley L, Opolon P, Tilly H, et al. TET2 inactivation results in pleiotropic hematopoietic abnormalities in mouse and is a recurrent event during human lymphomagenesis. Cancer Cell. 2011; 20:25-38. https://doi.org/10.1016/j.ccr.2011.06.003.

26. Couronné L, Bastard C, Bernard OA. TET2 and DNMT3A mutations in human T-cell lymphoma. N Engl J Med. 2012; 366:95-96. https://doi.org/10.1056/NEJMc1111708.

27. Nguyen TB, Sakata-Yanagimoto M, Nakamoto-Matsubara R, Enami T, Ito Y, Kobayashi T, Obara N, Hasegawa Y, Chiba S. Double somatic mosaic mutations in TET2 and DNMT3A - origin of peripheral T cell lymphoma in a case. Ann Hematol. 2015; 94:1221-23. https://doi.org/10.1007/ s00277-015-2332-0.

28. Wang M, Zhang S, Chuang SS, Ashton-Key M, Ochoa E, Bolli N, Vassiliou G, Gao Z, Du MQ. Angioimmunoblastic T cell lymphoma: novel molecular insights by mutation profiling. Oncotarget. 2017; 8:17763-17770. https://doi. org/10.18632/oncotarget.14846.

29. Swerdlow SH, Harris NL, Jaffe ES, Pileri SA, Stein H, Thiele J, Vardiman JW. WHO Classification of Tumours of Haematopoietic and Lymphoid Tissues. Lyon, France: IARC Press; 2008.

30. Attygalle A, Al-Jehani R, Diss TC, Munson P, Liu H, Du MQ, Isaacson PG, Dogan A. Neoplastic T cells in angioimmunoblastic T-cell lymphoma express CD10. Blood. 2002; 99:627-33. https://doi.org/10.1182/blood. V99.2.627.

31. Nagao R, Kikuti YY, Carreras J, Kikuchi T, Miyaoka M, Matsushita H, Kojima M, Ando K, Sakata-Yanagimoto M, Chiba S, Nakamura N. Clinicopathologic analysis of angioimmunoblastic T-cell lymphoma with or without RHOA G17V mutation using formalin-fixed paraffinembedded sections. Am J Surg Pathol. 2016; 40:1041-50. https://doi.org/10.1097/PAS.0000000000000651.

32. Ondrejka SL, Grzywacz B, Bodo J, Makishima H, Polprasert C, Said JW, Przychodzen B, Maciejewski JP, Hsi ED. Angioimmunoblastic T-cell lymphomas with the RHOA p.Gly17Val mutation have classic clinical and pathologic features. Am J Surg Pathol. 2016; 40:335-41. https://doi.org/10.1097/PAS.0000000000000555.

33. Nishizawa S, Sakata-Yanagimoto M, Hattori K, Muto H, Nguyen T, Izutsu K, Yoshida K, Ogawa S, Nakamura N, Chiba S. BCL6 locus is hypermethylated in angioimmunoblastic T-cell lymphoma. Int J Hematol. 2017; 105:465-69. https://doi.org/10.1007/s12185-016-2159-z. 
34. Asmar F, Punj V, Christensen J, Pedersen MT, Pedersen A, Nielsen AB, Hother C, Ralfkiaer U, Brown P, Ralfkiaer E, Helin K, Grønbæk K. Genome-wide profiling identifies a DNA methylation signature that associates with TET2 mutations in diffuse large B-cell lymphoma. Haematologica. 2013; 98:1912-20. https://doi.org/10.3324/haematol.2013.088740.

35. Langemeijer SM, Jansen JH, Hooijer J, van Hoogen P, Stevens-Linders E, Massop M, Waanders E, van Reijmersdal SV, Stevens-Kroef MJ, Zwaan CM, van den Heuvel-Eibrink MM, Sonneveld E, Hoogerbrugge PM, et al. TET2 mutations in childhood leukemia. Leukemia. 2011; 25:189-92. https://doi.org/10.1038/leu.2010.243.

36. Shimoda K, Shide K, Kameda T, Hidaka T, Kubuki Y, Kamiunten A, Sekine M, Akizuki K, Shimoda H, Yamaji T, Nakamura K, Abe H, Miike T, et al. TET2 mutation in adult T-cell leukemia/lymphoma. J Clin Exp Hematop. 2015; 55:145-49. https://doi.org/10.3960/jslrt.55.145.

37. da Silva Almeida AC, Abate F, Khiabanian H, MartinezEscala E, Guitart J, Tensen CP, Vermeer MH, Rabadan R, Ferrando A, Palomero T. The mutational landscape of cutaneous $\mathrm{T}$ cell lymphoma and Sézary syndrome. Nat Genet. 2015; 47:1465-70. https://doi.org/10.1038/ng.3442.

38. López C, Bergmann AK, Paul U, Murga Penas EM, Nagel I, Betts MJ, Johansson P, Ritgen M, Baumann T, Aymerich M, Jayne S, Russell RB, Campo E, et al. Genes encoding members of the JAK-STAT pathway or epigenetic regulators are recurrently mutated in T-cell prolymphocytic leukaemia. Br J Haematol. 2016; 173:265-73. https://doi. org/10.1111/bjh.13952.

39. Nagata $Y$, Kontani K, Enami T, Kataoka K, Ishii R, Totoki Y, Kataoka TR, Hirata M, Aoki K, Nakano K, Kitanaka A, Sakata-Yanagimoto M, Egami S, et al. Variegated RHOA mutations in adult T-cell leukemia/lymphoma. Blood. 2016; 127:596-604. https://doi.org/10.1182/ blood-2015-06-644948.

40. Kataoka K, Nagata Y, Kitanaka A, Shiraishi Y, Shimamura T, Yasunaga J, Totoki Y, Chiba K, Sato-Otsubo A, Nagae G, Ishii R, Muto S, Kotani S, et al. Integrated molecular analysis of adult $\mathrm{T}$ cell leukemia/lymphoma. Nat Genet. 2015; 47:1304-15. https://doi.org/10.1038/ng.3415.

41. Vaqué JP, Gómez-López G, Monsálvez V, Varela I, Martínez N, Pérez C, Domínguez O, Graña O, Rodríguez-Peralto JL, Rodríguez-Pinilla SM, González-Vela C, Rubio-Camarillo M, Martín-Sánchez E, et al. PLCG1 mutations in cutaneous T-cell lymphomas. Blood. 2014; 123:2034-43. https://doi. org/10.1182/blood-2013-05-504308.

42. Margolskee E, Jobanputra V, Jain P, Chen J, Ganapathi K, Nahum O, Levy B, Morscio J, Murty V, Tousseyn T, Alobeid B, Mansukhani M, Bhagat G. Genetic landscape of T- and NK-cell post-transplant lymphoproliferative disorders. Oncotarget. 2016; 7:37636-48. https://doi. org/10.18632/oncotarget.9400.

43. Li W, Gao C, Cui L, Liu S, Zhao X, Zhang R, Wu M, Zheng H, Deng G, Li Z, Zhang Q. DNMT3A mutations and prognostic significance in childhood acute lymphoblastic leukemia. Leuk Lymphoma. 2015; 56:1066-71. https://doi. org/10.3109/10428194.2014.947607.

44. Neumann M, Heesch S, Schlee C, Schwartz S, Gökbuget N, Hoelzer D, Konstandin NP, Ksienzyk B, Vosberg S, Graf A, Krebs S, Blum H, Raff T, et al. Whole-exome sequencing in adult ETP-ALL reveals a high rate of DNMT3A mutations. Blood. 2013; 121:4749-52. https://doi.org/10.1182/ blood-2012-11-465138.

45. Andersson EI, Rajala HL, Eldfors S, Ellonen P, Olson T, Jerez A, Clemente MJ, Kallioniemi O, Porkka K, Heckman C, Loughran TP Jr, Maciejewski JP, Mustjoki S. Novel somatic mutations in large granular lymphocytic leukemia affecting the STAT-pathway and T-cell activation. Blood Cancer J. 2013; 3:e168. https://doi.org/10.1038/bcj.2013.65.

46. Cheminant M, Bruneau J, Kosmider O, Lefrere F, Delarue R, Gaulard P, Radford I, Derrieux C, Hermine O, Lemonnier F. Efficacy of 5-azacytidine in a TET2 mutated angioimmunoblastic $\mathrm{T}$ cell lymphoma. $\mathrm{Br} \mathrm{J}$ Haematol. 2015; 168:913-16. https://doi.org/10.1111/bjh.13170.

47. Saillard C, Guermouche H, Derrieux C, Bruneau J, Frenzel L, Couronne L, Asnafi V, Macintyre E, Trinquand A, Lhermitte L, Molina T, Suarez F, Lemonnier F, et al. Response to 5-azacytidine in a patient with TET2-mutated angioimmunoblastic T-cell lymphoma and chronic myelomonocytic leukaemia preceded by an EBV-positive large B-cell lymphoma. Hematol Oncol. 2016.

48. Sakata-Yanagimoto M, Nakamoto-Matsubara R, Komori D, Nguyen TB, Hattori K, Nanmoku T, Kato T, Kurita N, Yokoyama Y, Obara N, Hasegawa Y, Shinagawa A, Chiba S. Detection of the circulating tumor DNAs in angioimmunoblastic T- cell lymphoma. Ann Hematol. 2017; 96:1471-75. https://doi.org/10.1007/s00277-017-3038-2.

49. Manso R, Bellas C, Martín-Acosta P, Mollejo M, Menárguez J, Rojo F, Llamas P, Piris MA, RodríguezPinilla SM. C-MYC is related to GATA3 expression and associated with poor prognosis in nodal peripheral T-cell lymphomas. Haematologica. 2016; 101:e336-38. https:// doi.org/10.3324/haematol.2016.143768.

50. Manso R, Roncador G, Montes-Moreno S, Rojo F, PérezSáenz MA, Mollejo M, Menárguez J, Carvajal N, GarcíaCosio M, Llamas P, Piris MA, Rodríguez-Pinilla SM. p-MAPK1 expression associated with poor prognosis in angioimmunoblastic T-cell lymphoma patients. Br J Haematol. 2017; 176:661-64. https://doi.org/10.1111/bjh.13972.

51. Rodríguez-Pinilla SM, Sánchez ME, Rodríguez J, García JF, Sánchez-Espiridión B, Lamana LF, Sosa G, Rivero JC, Menárguez J, Gómez IB, Camacho FI, Guillen PR, Orduña $\mathrm{CP}$, et al. Loss of TCR-beta F1 and/or EZRIN expression is associated with unfavorable prognosis in nodal peripheral T-cell lymphomas. Blood Cancer J. 2013; 3:e111. https:// doi.org/10.1038/bcj.2013.10. 